\title{
The Influence of Employability Skills and Skill Competency toward Work Readiness
}

\author{
$1^{\text {st }}$ Endah Setyo Wardani \\ Vocational Education \\ Postgraduate, Universitas Negeri Malang \\ Malang, Indonesia \\ endahstowri@gmail.com
}

\author{
$2^{\text {nd }}$ Isnandar \\ Department of Civil EngineeringEngineering Faculty, \\ Universitas Negeri Malang \\ Malang, Indonesia \\ isnandar.ft@um.ac.id
}

\author{
$3^{\text {rd }}$ Siti Sendari \\ Department of Electrical Engineering \\ Universitas Negeri Malang \\ Malang, Indonesia \\ siti.sendari.ft@um.ac.id
}

\begin{abstract}
The research aims to study influences of employability skills and skill competency toward work readiness. Data collections use questionnaires and score documentation, colected from 176 students at the XII grade of vocational school (SMK) of Electrical Power Instalation Technique in Malang Raya. The technical data analysis uses path analysis. The results show that employability skills influence toward work the readiness by $19.98 \%$ while skill competency influence that by 48.84\%.
\end{abstract}

Keywords-emloyability skills; skill competency; work readiness

\section{INTRODUCTION}

Sekolah Menengah Kejuruan (SMK) is a formal education of vocational schools, which implements skill-based competency, while it is expected to fulfill skills that are needed by business and industrial world. SMK graduates are expected to fulfill the demand of business world and the industry in terms of the provision of middle-level workers. Accoding to the Law of National Education System No. 20 The year 2003 Article 15, SMK is to prepare productive students who have high skill competencies. Students study a competency that will be used according to the business and industrial world. However, in reality SMK still face many problems related to the skill competencies.

Currently, SMK graduates are less ready to work in the business and industrial world, because the ability and experience of students to enter the business and industrial world are still lack [1]. In addition, the student's readiness to work in the business and industrial world hasn't been optimal, which can reduce the competency of SMK graduates, which can contribute new unemployments. According to the Statisticss Central Bureau (BPS) 2016, the number of unemployed in Indonesia on February 2016 reached 7.0 million people. From the data, unemployment rate (TPT) of SMK occupied level the highest position of 9.84 percent and followed by that of Diploma I/II/III, i.e., 7.22. Here, the lowest rate unemployament is on is obtained by the one who graduated from elementary school level, i.e, 3.44 percent.
According to BPS data, SMK graduates have difficulties to work in the business and industrial world. Thus, work readiness could be the important thing to be improved.

Work readiness is a condition of a person who has physically and mentally, ability to work and obtain skill ability by yearly experiences [2]. Therefore, SMK graduates should have work readiness to face a world of work, when they are graduated and they are expected to be able to perform and finish the job well. Furthermore, they have to know and understand the duties and responsibilities. However, the availability of SMK graduates have not been fully capability of generating labour supply due to two factors, that is lack of hard skills and soft skills [3]. To fulfill the needs of workfoce in business and industrial world, SMK prepares the that are provided with the productive subjects. Mastery is one of the indicators of student's skill level plays a role in preparing students to work, especially in terms of hard skills. While soft skills are related to employability skills. Employability skill is a basic skill that every worker should have a use, they also have to be able to adapt to the workplace. Employability skills can improve competitiveness and successes in increasing productivity and profitability[4]. One of the employee's criterias that required by the company is the employability skills [5]. Perceptions and expectations of the business and industrial world to get good workers, which have good emploability skills, SMK should fulfill this requirement.

\section{METHOD}

This research used quantitive research approach while the aim is to explain the influence of employability skills and skill competency toward work readiness. The population of this research is all students at the XII grade SMK of Electrical Power Instalation Technique in Malang Raya, i.e., SMK Negeri 6 Malang, SMK Nasional Malang, SMK Negeri 1 Singosari, SMK Muhammadiyah 7 Gondanglegi, SMK Brantas Karangkates, and SMK Turen. While the number of samples is 176 students. In detail, the number of samples in each SMK is shown in Table I. 
TABLE I POPULATION AND SAMPLE OF RESEARCH

\begin{tabular}{|l|l|l|}
\hline \multicolumn{1}{|c|}{ SMK } & \multicolumn{1}{|c|}{ Populasi } & \multicolumn{1}{c|}{ Sampel } \\
\hline SMK Negeri 6 Malang & 67 students & 37 students \\
\hline SMK Nasional Malang & 20 students & 11 students \\
\hline SMK Muhammadiyah 7 Gondanglegi & 35 students & 20 students \\
\hline SMK T uren & 46 students & 26 students \\
\hline SMK Brantas Karangkates & 79 students & 44 students \\
\hline SMK Negeri 1 Singosari & 68 students & 38 students \\
\hline Jumlah & 315 students & 176 students \\
\hline
\end{tabular}

Data collections in this research are collected using questionnaires and score documentations. The questionnaire is used to obtain data related to a variable of employability skills and work readiness. While, score documentation is to obtain the value of skill competency, which is a score of student examinations (UKK).

The analytical technique uses path analysis, that is used to examine the influence addressed by the employability skills and skill competency.

\section{RESEARCH RESULT}

\section{A. Research Variables}

Variables which are used in this research consist of employability skills (X), skill competency (Y), and work readiness $(Z)$. This research studies about the influence of employability skills (X) toward work readiness (Z) and skill competency $(\mathrm{Y})$ toward work readiness $(\mathrm{Z})$ and it is shown in Figure I.

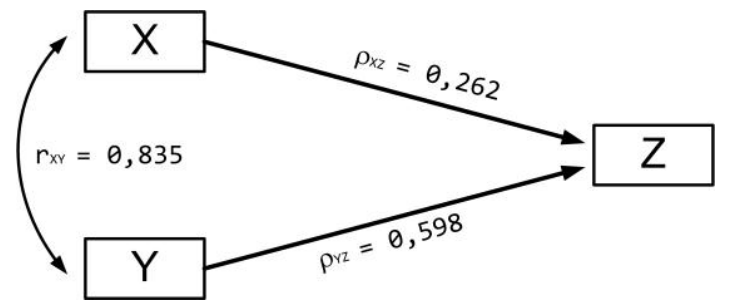

Fig I. Path Diagram of Empirical Relation of $\mathrm{X}_{3}$ and $\mathrm{Y}$ toward $\mathrm{Z}$

\section{B. Statistical Analysis}

The data research is analyzed using the statistical tools, that is SPSS version 21.0 for windows using 176 data. Employability skills (X), skill competency (Y), and work readiness (Z) are shown Table II. Here, data has been analyzed as a minimum, maximum, mean, standard deviation, and variance.

TABLE II. DESCRIPTIVE STATISTIC

\begin{tabular}{|c|r|r|r|r|r|c|}
\hline Variabel & N & Min. & Max. & Mean & $\begin{array}{c}\text { Std. } \\
\text { Dev. }\end{array}$ & Var. \\
\hline Employability Skills & 176 & 84 & 112 & 99,03 & 6,54 & 42,80 \\
\hline Skill Competency & 176 & 79,00 & 98,20 & 88,70 & 4,04 & 16,34 \\
\hline Work Readiness & 176 & 53 & 84 & 71,03 & 5,99 & 35,84 \\
\hline
\end{tabular}

On the other hand, where the data has been analyzed using regression method. The results show that Rsquare value of
0.689 and $F$ of 191.575 with a significance value of 0.000 as shown in Table III. It means that there is a significant influence on employability skills (X) and competency skill (Y) toward work readiness (Z), so individual testing can be done. Individual testing is done between one independent variable with the dependent variable.

TABLE III. ANOVA X AND Y TOWARD Z

\begin{tabular}{|c|c|r|r|r|r|r|}
\hline \multicolumn{2}{|c|}{ Model } & Sum of Squares & Df & Mean Square & F & Sig. \\
\hline & Regression & 4320,849 & 2 & 2160,425 & 191,575 &, $000^{\circ}$ \\
\cline { 2 - 7 } 1 & Residual & 1950,946 & 173 & 11,277 & & \\
\cline { 2 - 7 } & Total & 6271,795 & 175 & & & \\
\hline \multicolumn{7}{l|}{ a. Dependent Variable: $Z$} \\
\hline \multicolumn{7}{|l}{ b. Predictors: (Constant) Y, X } \\
\hline
\end{tabular}

Table IV shows that there is a correlation among variables. Based on analysing obtained by the SPSS, a correlation value between employability skills and skill competency is 0.835 , a value between employability skills and work readiness is 0.762 , and value between skill competency and work readiness is 0.817 . The results mean that every variable has a strong relationship with the other variables, because correlation value is more than 0.05 .

TABLE IV. CORRELATIONS

\begin{tabular}{|l|l|r|r|r|}
\hline \multicolumn{2}{|c|}{} & \multicolumn{1}{|c|}{ X } & \multicolumn{1}{c|}{ Y } & \multicolumn{1}{c|}{ Z } \\
\hline \multirow{3}{*}{ X } & Pearson Correlation & 1 &, 835 &, 762 \\
\cline { 2 - 5 } & Sig. (2-tailed) & &, 000 &, 000 \\
\cline { 2 - 5 } & N & 176 & 176 & 176 \\
\hline \multirow{3}{*}{$Y$} & Pearson Correlation &, 835 & 1 &, 817 \\
\cline { 2 - 5 } & Sig. (2-tailed) &, 000 & &, 000 \\
\cline { 2 - 5 } & N & 176 & 176 & 176 \\
\hline \multirow{3}{*}{$Z$} & Pearson Correlation &, 762 &, 817 & 1 \\
\cline { 2 - 5 } & Sig. (2-tailed) &, 000 &, 000 & \\
\cline { 2 - 5 } & N & 176 & 176 & 176 \\
\hline
\end{tabular}

Considering the significant values as shown in Table V, the influences of employability skills (X) toward work readiness $(\mathrm{Z})$ and skill competency $(\mathrm{Y})$ toward work readiness (Z) are significant and positive.

TABLE V. COEFFICIENT X3, AND Y TO WARD Z

\begin{tabular}{|c|c|c|c|c|c|c|}
\hline & \multirow{2}{*}{ Model } & \multicolumn{2}{|c|}{ Unstandardized Coefficients } & \multirow{2}{*}{$\begin{array}{c}\text { Standardized } \\
\text { Coefficients } \\
\text { Beta }\end{array}$} & \multirow{2}{*}{$\mathbf{T}$} & \multirow{2}{*}{ Sig. } \\
\hline & & $\overline{\mathbf{B}}$ & Std. Error & & & \\
\hline \multirow{3}{*}{1} & (Constant) & $-31,3250$ & 5,767 & & $-5,436$ &, 000 \\
\hline & $\mathrm{X}$ &, 240 &, 070 &, 262 & 3,408 &, 001 \\
\hline & $\mathrm{Y}$ & ,886 &, 114 & ,598 & 7,769 &, 000 \\
\hline
\end{tabular}

\section{Result Analysis}

1) Employability Skills Influence Work Readiness

The individual test shows that the result of path coefficient on employability skill variable toward work readiness $\left(\rho_{Z X}\right)$ is 0,262 and significance value. 0.001 as shown in Table V. Since, the significance value is less than 0.05 , so it means there is a significant influence of employability skills to work 
readiness. The direct influence of employability skill to work readiness that is equal to 0.069 , or equal to $6.9 \%$. While the indirect influence of employability to work readiness indirectly can use the following equation:

$$
\mathrm{n} 1 \text { through } n_{2}=\rho_{Z n 1} \rho_{Z n 2} r_{n l n 2}
$$

Where, this $\rho_{Z n 1}$ is path coefficient value of $n_{1}$ toward $Z$, and $\rho_{\mathrm{Zn} 2}=$ path coefficient value of $\mathrm{n}_{2}$ toward $\mathrm{Z}$. So this equation, the indirect influence of employability skills toward work readiness including skill competency is $13.08 \%$.

\section{2) Skill Competency Influence Work Readiness}

The individual test shows that the result of path coefficient on skill competency variable toward work readiness $\left(\rho_{Z Y}\right)$ is 0,598 and sig value. 0,000 as shown in Table V. Since, the significance value is less than 0.05 , so it means there is a significant influence of skill competency to work readiness. The direct influence of skill competency to work readiness directly that is equal to 0,3576 , or equal to $35,76 \%$. While the indirect influence of skill competency to work readiness can use "(1)", including employability skills is $13.08 \%$.

\section{DISCUSSION}

\section{A. Influence of Emloyability Skills toward Work Readiness}

Employability skills are non-technical competencies that aim to be effective and successful to participate in the business and industrial world. The result of the research shows that the students' Electrical Power Instalation Technique in Malang Raya have average employability skill of 99.03. This result indicates that the students of Electric Power Installation Technique have good employability skills to work readiness. Here school succeeds in applying employability skills for students. Employability skills are important for students who work in the business and industrial world. Therefore, teachers must make the value of employability skills in the learning process, so that students understand that soft skills are needed by a worker.

To improve employability skills in graduates and contribute to the work readiness, not only in the cognitive domain, so school require to improve also in the affective domain [6]. The emotional, social, and coginitive skills will help to optimize students' employability skills. The industry considers employability skills which are important and must be owned by SMK graduates to ensure that they have skills to work. Even they have technical skills need higher level skill in order to fulfill the work readiness. This skill can be improved in term of motivation, communication, interpersonal skills, critical thinking, problem solving that is part of employability skills. So they can contribute to increasing productivity [7]-[9].

In this research shows that there is a direct influence of employability skill toward work readiness, i.e., $6.9 \%$ and indirect influence of employability skill toward work readiness, i.e., $13.08 \%$, so the total influence of employability skill to work readiness equal is 19.98. Students who have employability skills can be told that students also have work readiness comparing with they have no technical skills to work.

Employability skills in terms of listening, collaboration, and innovation skills are important, so the students should be aware of improving the skills [10]. The research also suggests that there is an important thing to develop work skills readiness to ensure supply and demand in order to face business and industrial world.

\section{B. Influence of Skill Competency toward Work Readiness}

Skill competency of Electrical Power Installation Technique is one of the skill competencies in SMK, which must be owned by students. Skill competency is assessed through skill competency test (UKK) to 1) measure the achievement of skill competency of SMK students'; 2) provide a certificate for SMK's student who has complete the education; and 3) optimize the implementation of competency skill certification by SMK.

Based on the UKK assessment guidelines, there are five components to determine final score, i.e., 1) preparation of $10 \%, 2$ ) process of $40 \%, 3$ ) work attitude of $15 \%, 4)$ result of $15 \%$, and 5) time of $10 \%$. The results showed that the skill competency of Electrical Power Instalation Technique of students at the XII grade in Malang Raya have an as good category with the percentage of $54.55 \%$, while the average of all students is 88.7. This result showed that students had obtained good competence, and able to compete in the business and industrial world. Facilities in SMK will support students to improve the competence of their skills.

Competence is a combination of knowledge and skills, which involve also the ability to fulfill complex needs by utilizing and mobilizing resources within specific content [11]. The assessment result showed the aspects of skills, attitude, management, time, and process.

Skill competency plays the role to develop work readiness of students, because when graduated, the students face problems related to knowledge and skills what have learned in SMK, whether it is sufficient or not to work [12]. In order to support the skill competency of students in preparing to work, the learning process should be added special assistance so that students are encouraged to have more skill competencies and to prepare themselves to work in business and industrial world.

This research showed that the direct influence of skill competency toward work readiness, i.e., $35.76 \%$ and the indirect influence of skill competency toward work readiness, i.e., $13.08 \%$, so that the total influence of skill competency to work readiness is $48.84 \%$. It is also related to the other research that there is a positive and significant influence between vocational basic learning achievement to work readiness of SMK Study Program of Electronic Engineering in Sleman 9\% and SMKN 2 Yogyakarta [13], [14].

\section{CONCLUSIONS}

Based on the result, the research concluded that employability skills and skill competency have significant influence toward work readiness. There is the influence of 
employabiity skills toward work readiness, i.e., 19.98\%. There is the influence of skill competency toward work readiness, i.e., $48.84 \%$. According to that, employabilityskill and skill competency should be improved by SMK through adding facilities, and learning process.

\section{REFERENCES}

[1] A. P. Sasmito, D. Kustono, and S. Patmanthara, "Kesiapan Memasuki Dunia Usaha/Dunia Industri (DU/DI) Siswa Paket Keahlian Rekaya Perangkat Lunak di SMK," vol. 38, no. 1,pp.2540, 2015.

[2] I. T. W. Nurjanah, "Pengaruh Praktik Kerja Industri terhadap Kesiapan Kerja Siswa Kelas XII Kompetensi Keahlian Administrasi Perkantoran SMK Negeri 1 Wonosari," Universitas Negeri Yogyakarta, 2015.

[3] H. Kartini, Supriyono, and S. E. Winahyu, "SMK dan DUDI, But uh Sin-kronisasi," 2012. [Online]. Available: http://www.penyelarasan.kemdiknas.go.id/content/detail/232.html. [Accessed: 15-May-2016].

[4] M. R. Bloom and K. G. Kitagawa, "Understanding Employability Skills," 1999. [Online]. Available: http://www.accc.ca/wpcontent/uploads/archive/es-ce/257_99.pdf. [Accessed: 15-May2016].

[5] D. Hull, Career Pathway: Education wih A Purpose. Waco: Cord, 2005.

[6] S. Bandaranaike and J. Willison, "Building Capacity for WorkReadiness: Bridging Cognitive and Effective Domains," . AsiaPacific J. Coop. Educ., no. 2000, 2015.

[7] F. A. Halim, A. R. Bakar, R. Hamzah, and A. M. Rashid, "Employability Skills of Technical and Vocational Students with Hearing Impairements: Employers' Perspectives,” J. Tech. Educ.
Train., vol. 5, no. 2, pp. 65-74, 2013.

[8] M. S. Rasul, I. M. Yusof, N. Ismail, R. Rajuddin, and R. A. Rauf, “Aspek Kemahiran ‘Employability' yang Dikehendaki Majikan Industri Pembuatan Masa Kini (Aspects of Employability Skills Needed by The Manufacturing Industries Employers)," J. Pendidik. Malaysia, vol. 34, no. 2, pp. 67-79, 2009.

[9] A. R. Madar, M. A. A. Aziz, and R. A. R. Abd, "Kemahiran Employability bagi Memenuhi Keperluan Industri," in Seminar Kebangsaan Kemahiran Insaniah dan Kesejahteraan Sosial (SKIKS), 2008, pp. 385-392.

[10] E. Tanius and S. Susah, "Employability Skill Readiness among Business 'Students,” Int. J. Sci. Res., vol. 4, no. 8, pp. 511-516, 2015.

[11] D. S. Rychen and L. H. Salganaik, "Defining and Selecting Key Competencies,” 2001. [Online]. Available: https://www.oecd.org/pisa/35070367.pdf. [Accessed: 13-Jun-2017].

[12] I. D. H. Setiyawan and S. Hadi, "Pengaruh Prestasi Belajar Kejuruan dan Praktik Kerja Industri terhadap Kesiapan Kerja Siswa Jurusan Teknik Permesinan SMKN 3 Yogyakarta," E-Jurnal Pendidik. Tek. Mesin, vol. 2, 2013.

[13] A. A. Baiti and S. Munadi, "Pengaruh Pengalaman Praktik, Prestasi Belajar Dasar Kejuruan dan Dukungan Orang Tua terhadap Kesiapan Kerja Siswa SMK,” J. Pendidik. Vokasi, vol. 4, no. 2, pp. 164-180, 2014.

[14] I. R. Harja, "Pengaruh Kompetensi Kerja dan Motivasi Kerja terhadap Kesiapan Kerja Siswa Kelas XII Program Studi Teknik Instalasi T enaga Listrik SMKN 2 Yogyakarta," Universitas Negeri Yogyakarta, 2013. 